\title{
Reproductive period and fecundity of Serrapinnus piaba (Characidae: Cheirodontinae) from the rio Ceará Mirim, Rio Grande do Norte, Brazil
}

\author{
Jacira Silvano*, Cristina L. C. Oliveira**, \\ Clarice B. Fialho** and Hélio C. B. Gurgel***
}

Specimens of Serrapinnus piaba were collected monthly from April 2001 to April 2002 in the rio Ceará Mirim, Rio Grande do Norte State, Brazil. The reproductive period, determined through the monthly variation of the gonadosomatic index (GSI) and maturation stages, occurred from January to April. Non-parametric Spearman test was performed in order to test correlation of monthly GSI variation in males and females with water temperature, rainfall and day length. Rainfall and Temperature were correlated with GSI variation in females only and day length showed a negative correlation with GSI variation of males only. It was verified the presence of hooks on the anal fin of mature and maturing males along all the period of study. The absolute fecundity mean was $441( \pm 178.08)$ oocytes, determined by the number of yolky oocytes counted in 27 mature female gonads. The relative fecundity, estimated by the number of yolky oocytes divided by milligram of total body weight was $0.74( \pm 0.19)$.

Espécimes de Serrapinnus piaba foram coletados mensalmente de abril de 2001 a abril de 2002, no rio Ceará Mirim, Rio Grande do Norte, Brasil. O período reprodutivo, determinado através da variação mensal do índice gonadossomático (IGS) e estádios de maturação gonadal, ocorreu de janeiro a abril. Utilizou-se o teste não paramétrico de Spearman para testar a correlação entre a variação mensal do IGS de machos e fêmeas com temperatura da água, pluviosidade e fotoperíodo. A correlação entre IGS e pluviosidade e IGS e temperatura foi significativa para as fêmeas somente. A correlação entre o fotoperíodo e IGS foi significativa e negativa somente para os machos. Verificou-se a presença de ganchos na nadadeira anal de machos em maturação e maduros durante todo o período de estudo. A fecundidade absoluta média, estimada através da contagem dos ovócitos vitelinados de 27 fêmeas maduras, foi de 441 ( \pm 178.08 ) ovócitos. A fecundidade relativa, estimada através do número de ovócitos vitelinados produzidos por mg de peso, foi de $0.74( \pm 0.19)$ ovócitos por miligrama de peso total.

Keywords: reproduction, fin hooks, Neotropical, Cheirodontini.

\section{Introduction}

The subfamily Cheirodontinae is constituted by small characid fish species, usually with a maximum of $30-40 \mathrm{~mm}$ of standard length. They are generally abundant in lentic and lowland waters, occurring in the South and Central Americas and being the only Characiformes found west slope of the Andes, in Chile (Malabarba, 1998). The Cheirodontinae are characterized by the presence of a triangular opening in the musculature covering the anterior part of the swim bladder in both sides of the body, named pseudotympanum. Besides this character, the shape of the teeth, pedunculated and expanded in its distal portion, the presence of a single series of teeth in the premaxilla and the absence of a humeral spot diagnose the members of this subfamily (Malabarba, 1998).

\footnotetext{
* Programa de Pós-Graduação em Ecologia, Universidade Federal do Rio Grande do Sul. Av. Bento Gonçalves 9500, Prédio 43422, 90540-000 Porto Alegre, RS, Brazil; and Universidade do Extremo Sul Catarinense, Av. Universitária, 1105, Caixa Postal 3167, Bairro Universitário, 88806-000 Criciúma, SC, Brazil. e-mail: jsi@unesc.rct-sc.br

** Laboratório de Ictiologia, Departamento de Zoologia e Programa de Pós-Graduação em Biologia Animal, Universidade Federal do Rio Grande do Sul. Av. Bento Gonçalves 9500, Prédio 43435, 90540-000 Porto Alegre, RS, Brazil

*** Laboratório de Fisiologia e Ecologia de Peixes, Departamento de Fisiologia, Universidade Federal do Rio Grande do Norte, P.O.Box 1511, 59072-970 Natal, RN, Brazil
} 
Serrapinnus piaba (Lütken, 1874) is a small cheirodontine with external fertilization, with a distribution covering the São Francisco river basin and coastal rivers of northeastern Brazil down to Espírito Santo state (L. R. Malabarba, pers. comm.). Until not long ago this species was referred in the genus Cheirodon Girard, 1855. However, given the study made by Malabarba (1998) this species was transferred to the genus Serrapinnus Malabarba, 1998, tribe Cheirodontini by sharing with other species of this genus several derived characters related to the shape of the anal fin rays and procurrent ventral caudal-fin rays of males.

Few works have been done on the reproductive biology in Cheirodontinae. Gelain et al. (1999) described reproductive aspects of Serrapinnus calliurus (Boulenger, 1900). Braum et al. (2000) described the reproductive biology of Cheirodon ibicuhiensis Eigenmann, 1915, while Oliveira et al. (2002) treated the reproductive period, spawning and fecundity of the same species. It is worth mentioning that all these works were done in southern Brazil, in a subtropical climate. Sendra \& Freyre (1981) studied growth and survival in Cheirodon interruptus (Jenyns, 1842). Burns et al. (1997) described the morphology of the spermatozoid in inseminating cheirodontines (those species which males transfer spermatozoids to female ovaries, but no developing embryos are found and the exact moment of fecundation is unknown).

Vazzoler \& Menezes (1992) stated that knowledge of the reproductive tactic is fundamental to understand the life cycle strategies of the species. Adebisi (1987) comments that fecundity estimates are important to identify the production potential and consequently the exploitation and management of the species. Given that, and added to the shortage of information on the reproductive biology of cheirodontine species from Tropical zones, the present work aims to the describe the reproductive period of $S$. piaba from the rio Ceará-Mirim, Rio Grande do Norte, Brazil, correlating that with abiotic data and estimating the absolute and relative fecundities.

\section{Materials and Methods}

The studied specimens were collected in the rio Ceará Mirim (5'37'47' S and 35'37'9' W), in the município de Taipú, Distrito de Umari, state of Rio Grande do Norte, Brazil, from April 2001 to April 2002, totalizing 4,218 individuals. The rio Ceará Mirim is one of the main hydrographical basins of the Rio Grande do Norte state, with approximately 2,770 km2 (Nóbrega-Júnior, 1986). At the collecting point, the bottom of the river is sandy and the maximum depth is $1.20 \mathrm{~m}$. The river has a maximum width of $5 \mathrm{~m}$; the water is transparent alternating middle velocity water and still areas. There are abundant floating and submerged vegetation, and just grasses at river margins.

The fishes were collected with a seine net, $5 \mathrm{~mm}$ mesh, being the animals fixed in $10 \%$ formaldehyde in the field. In the laboratory, the specimens were transferred to ethanol $70 \%$, and taken random sub samples of 40 individuals each (20 males and 20 females) monthly. The following data were taken of each specimen: standard length (Lp) in mm, total weight (Wt) and gonad weight (Wg) in grams. Voucher specimens were catalogued in the fish collection of Universidade Federal do Rio Grande do Sul (UFRGS 5807).

The presence of anal fin hooks was observed for males to correlate with the degree of male gonadal maturation.

Monthly relative frequencies of the gonadal maturation stages were estimated for males and females. The gonadal maturation stages of the females were classified as in maturation, mature, spawning and spent, considering macroscopic characters as color, vascularization, presence or absence of oocytes and gonad size in relationship with the abdominal cavity, following Vazzoler (1996). Male gonads were classified according to Oliveira (2003), as follows: immature - transparent, narrow and visible only under microscope; only spermatogonia are found under histological analysis. In maturation - white, slender, visible at dissection without microscope; under histology, presents several spermatogonia, primary and secondary spermatocytes, a few spermatides and spermatozoids. Mature - white, large and thick, with irregular borders; under histology, presents all stages of spermatogenesis (spermatogonia, primary and secondary spermatocytes, spermatides and spermatozoids) and mature sperm filling testicular tubules.

Some gonads of males and females identified macroscopically as each maturation stage were checked through histological analysis. Gonads were dehydrated and included in paraffin; and sectioned at $5 \mu \mathrm{m}$ in a Leica microtome, model RM 2145. Sections were stained with Hematoxylin and Eosin.

The reproductive period was determined through the analysis of the monthly variation of the mean of the gonadosomatic index (GSI), based on Santos (1978), as well as by the monthly variation of the relative frequencies of the gonadal maturation stages. The GSI was calculated through the following expression: $\mathrm{GSI}=(\mathrm{Wg} / \mathrm{Wt}) \times 100$, where $\mathrm{Wg}=$ gonad weight and $\mathrm{Wt}=$ total weight.

The absolute fecundity was estimated counting all yolk oocytes present in 27 mature ovaries. Relationships of absolute fecundity with standard length (Ls) and total weight (Wt) were established using the least squares method. The relative fecundity was estimated by the number of oocytes produced divided by body weight ( $\mathrm{g}$ ), according to Adebisi (1987).

The data on rainfall were obtained through Empresa de Pesquisa Agropecuária of Rio Grande do Norte state, northeastern Brazil. Photoperiod data (sunrise and sunset times) were obtained through the SkyMap software. Water temperature was taken with a thermometer at the time of collection. The non-parametric Spearman test was used to verify the correlation between GSI and abiotic data. 
Females
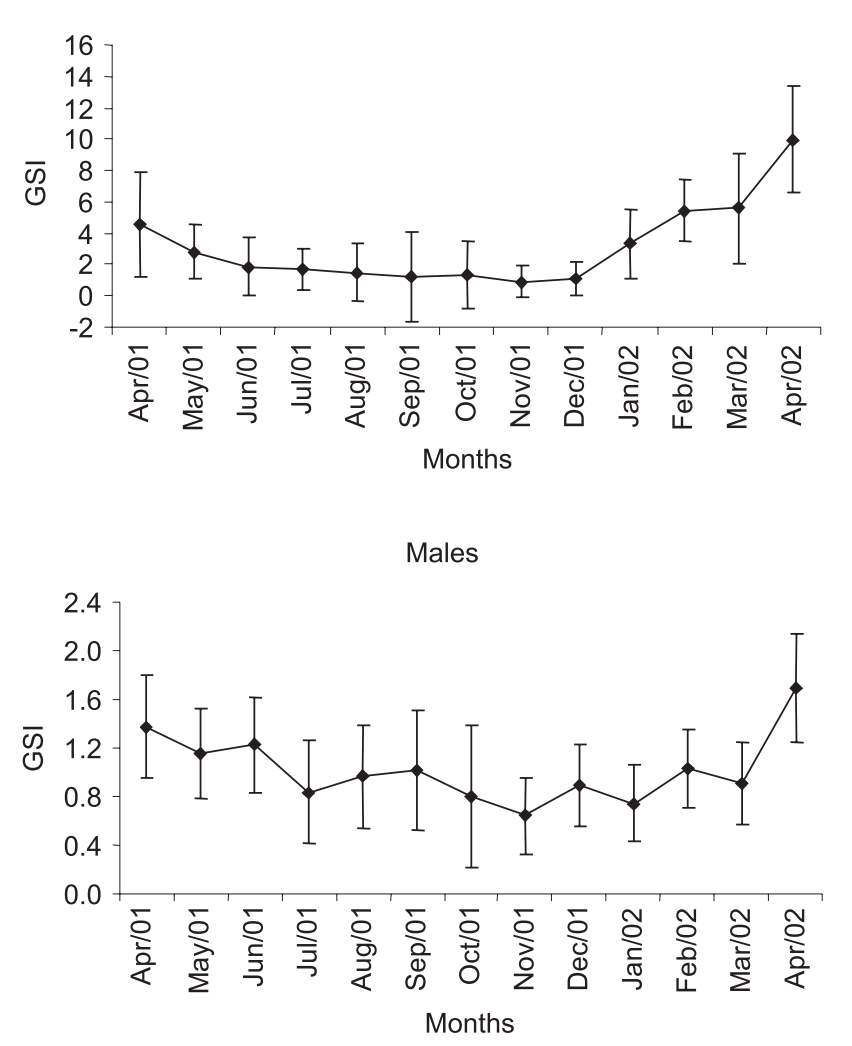

Fig. 1. Monthly variation of the mean of the gonadosomatic index (GSI) for males and females of Serrapinnus piaba collected in the rio Ceará Mirim, from April 2001 to April 2002. Vertical bars represent the standard deviation (SD).

\section{Results}

We analyzed 254 males and 254 females, with standard lengths varying from 20.22 to $30.18 \mathrm{~mm}$ for females and from 21.73 to $28.42 \mathrm{~mm}$ for males.

The gonadal maturation curve (Fig. 1) indicates that the reproductive period of S. piaba females start in January, when GSI increases, reaching the highest GSI mean in April. The monthly distribution of the relative frequencies of gonadal maturation stages (Fig. 2) shows females in maturation in October; mature and spawning females are found from January through the end of the study, in April 2002, with a predominance of the mature stage.

High GSI means were observed all over the year in males (Fig. 1). However, there is a peak in GSI mean in April 2002 coinciding with the GSI peak observed for females. The monthly distribution of the relative frequencies of gonadal maturation stages for males showed the mature stage was present during all the studied period (Fig. 2). Males also presented spermatogenic activity in the testis all along the year, as observed through histology.
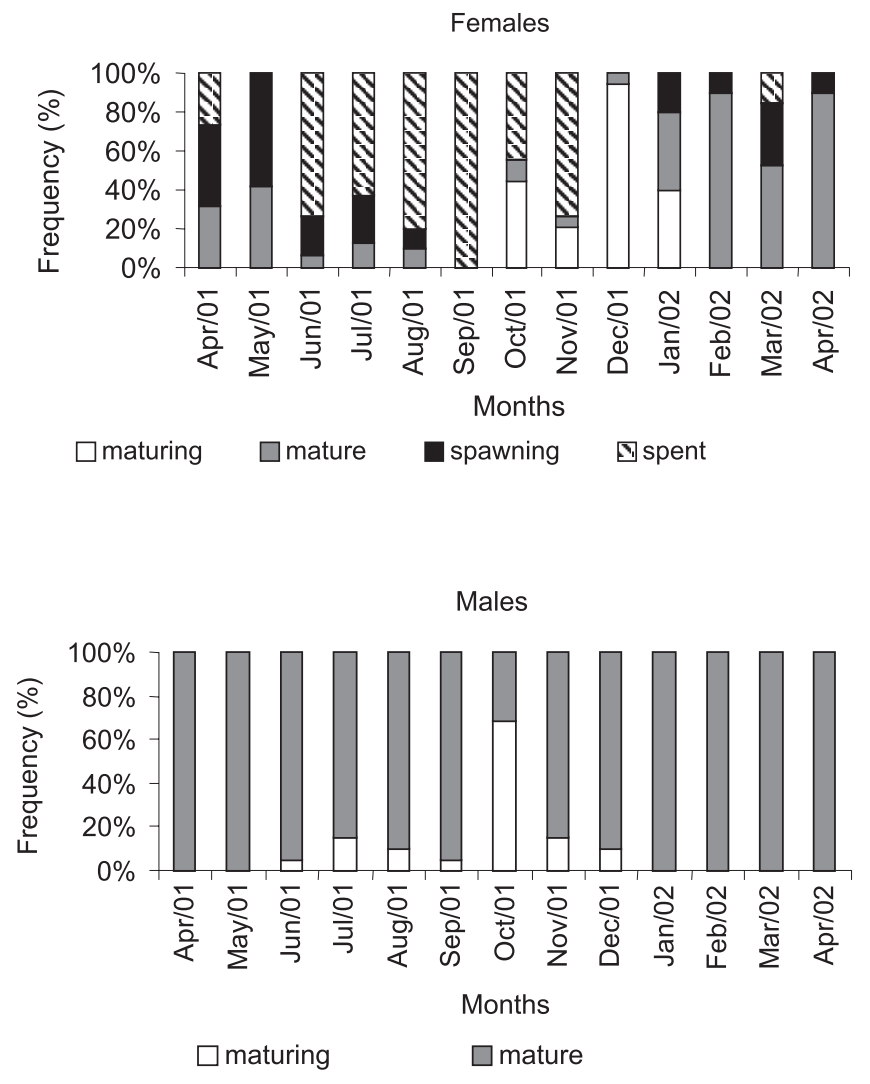

Fig. 2. Monthly variation of the frequencies of the gonadal maturity stages determined according to macroscopic observation of the gonads for males and females of Serrapinnus piaba collected in the rio Ceará Mirim from April 2001 to April 2002.

All in maturation and mature males had well-developed hooks along the anterior five to seven branched anal-fin rays. No immature males were collected. Hooks were present in males along all the studied period.

The absolute fecundity had an average value of 441 ( \pm 178.08 ) oocytes, with a range of 190 to 835 , corresponding to 27 females with standard lengths of 23.46 to $30.18 \mathrm{~mm}$. Relationships between absolute fecundity and standard length was adjusted to potential equation (Fecundity $=2 \mathrm{E}-05 \mathrm{SL}^{4.9948}$ ) and between absolute fecundity and total weight was adjusted to exponential equation (Fecundity $=94.968 \mathrm{e}^{2.4801 \mathrm{WT}}$ ). The average relative fecundity was $0.74( \pm 0.19)$ oocytes per $\mathrm{mg}$ total weight.

According to the Table 1, the water temperature data obtained during the study period had a range of $21.5^{\circ} \mathrm{C}$ (September) to $32.0^{\circ} \mathrm{C}$ (April). Total pluviosity varied from 0 $\mathrm{mm}$ in September and October to $192.5 \mathrm{~mm}$ in April and the photoperiod had a 39 minutes variation (Table I).

The correlation between GSI and pluviosity was not significant for males $(r=0.03$ and $\mathrm{p}>0.3195)$ but significant for females $(r=0.69$ and $p>0.009)$. For temperature the 
correlation was again significant for females ( $\mathrm{r}=0.68$ and $p<0.010)$, whilst for males this did not occur $(r=0.46$ and $\mathrm{p}>0.107)$. For the photoperiod the correlation obtained was significant and negative for males $(r=-0.55$ and $p<$ 0.047), with the same not valid for females $(r=-0.21$ and $p$ $>0.475$ ).

\section{Discussion}

Serrapinnus piaba lives in the Brazilian northeast, a region characterized by periods with intense pluviometric precipitation but also long dry periods. In the studied area it was observed a period of low pluviosity, from July to December, and two periods of high pluviosity from April to June 2001 and from January to March 2002. The correlation between female GSI variation and pluviosity values was significant, showing that the reproductive cycle of this species coincides with periods of maximum pluviosity. The reproductive period of fish species inhabiting low latitudes, as in northeastern Brazil, is generally associated with an increase in pluviosity, which exerts an indirect influence on the reproductive period of such species, since it contributes with an increase in food availability. According to Vazzoler \& Menezes (1992) and Bye (1989) floods provoked by high pluviosity resulted in a nutrient increment for the environment, which would help triggering reproduction, as well as helping larval survival. This species starts reproduction associated with rainfall and is classified as seasonal-strategist according to the patterns described by Winemiller (1989). The correlation between pluviosity and GSI was also significant for females of Compsura heterura, other cheirodontine collected in the rio Ceará Mirim in the same period as S. piaba (Oliveira, 2003).

On the other side, the reproductive period of fish species in southern Brazil, where there are no clearly marked periods of higher or lower pluviosity, is generally associated to photoperiod, as demonstrated for males and females of
Odontostilbe sp. (Oliveira, 2003) and for Diapoma speculiferum (Azevedo et al., 2000) studied in higher latitudes (29 50' $14^{\prime \prime} \mathrm{S}, 30^{\circ} 22^{\prime} 62^{\prime \prime} \mathrm{S}$, respectively). This marked influence of photoperiod on the reproductive period of species in higher latitudes in southern Brazil (as described for $D$. speculiferum and Odontostilbe sp.), whereas it has no marked influence in lower latitudes (as observed in S. piaba) is more easily understood comparing the time difference between longest and shortest day lengths in both examples, that correspond to 232 minutes in the south whilst in the northeast it is only 39 minutes.

The reproductive period of $S$. piaba, comprising the Summer months and the beginning of the Autumn, was only detected through the average monthly variation of GSI and gonadal maturation stages of the females, since the GSI showed little monthly variation in males. This could be indicative of continuous gonad activity in males, which was confirmed through the histological analysis of the testes where all phases of spermatogenesis were observed (spermatogones, spermatocytes, spermatides and spermatozoids), in both reproductive and non-reproductive periods. Males of C. heterura were also active all over the year (Oliveira, 2003). For females the reproductive period is evident through the significant accumulation of vitellum in the oocytes during maturation, with higher values of GSI between January and April. This indicates that spawning period is determined by female's maturation that occurred along a short period of the year. These females seem to have parcelled spawning, as determined by the recognition of empty follicles and different phases of oocyte development in the ovaries of spawning females.

According to Vazzoler (1996) fecundity depends on the volume of the coelomatic cavity available to house the mature oocytes and the size (volume) of these. Fecundity and mature oocyte diameter are very labile, varying between the reproductive periods and between individuals of the same size and in the same reproductive period (Vazzoler, 1996). According to Hartz et al. (1994), all vitellinate oocytes must

Table 1. Abiotic data (rainfall, day length and temperature) and monthly variation of the means of the gonadosomatic index (GSI) ( \pm standard deviation) for males and females of Serrapinnus piaba, collected in the rio Ceará Mirim, from April 2001 to April 2002.

\begin{tabular}{cccccc}
\hline Months & Males GSI & Females GSI & $\begin{array}{c}\text { Rainfall } \\
(\mathrm{mm})\end{array}$ & $\begin{array}{c}\text { Day length } \\
(\mathrm{min} .)\end{array}$ & $\begin{array}{c}\text { Temperature } \\
\left({ }^{\circ} \mathrm{C}\right)\end{array}$ \\
\hline Apr/01 & $1.3764 \pm 0.42$ & $4.5754 \pm 3.3$ & 192.5 & 716 & 32.7 \\
May/01 & $1.1479 \pm 0.37$ & $2.8257 \pm 1.72$ & 11.6 & 712 & 27.0 \\
Jun/01 & $1.2265 \pm 0.39$ & $1.8637 \pm 1.89$ & 108.3 & 708 & 26.0 \\
Jul/01 & $0.8381 \pm 0.43$ & $1.6946 \pm 1.29$ & 37.0 & 709 & 23.5 \\
Aug/01 & $0.9640 \pm 0.42$ & $1.4995 \pm 1.88$ & 20.4 & 714 & 24.5 \\
Sep/01 & $1.0204 \pm 0.49$ & $1.2632 \pm 2.87$ & 0.0 & 724 & 21.5 \\
Oct/01 & $0.7986 \pm 0.59$ & $1.3288 \pm 2.10$ & 0.0 & 733 & 24.0 \\
Nov/01 & $0.6391 \pm 0.32$ & $0.9105 \pm 1.01$ & 18.2 & 741 & 24.5 \\
Dec/01 & $0.8954 \pm 0.34$ & $1.1106 \pm 1.09$ & 3.6 & 747 & 28.8 \\
Jan/02 & $0.7451 \pm 0.31$ & $3.3132 \pm 2.24$ & 103.0 & 742 & 27.5 \\
Feb/02 & $1.0336 \pm 0.32$ & $5.4294 \pm 1.95$ & 57.8 & 734 & 28.5 \\
Mar/02 & $0.9068 \pm 0.34$ & $5.6042 \pm 3.51$ & 180.1 & 728 & 29.5 \\
Apr/02 & $1.6923 \pm 0.44$ & $9.9705 \pm 3.37$ & 36.0 & 716 & 30.0 \\
\hline
\end{tabular}


be considered to estimate fecundity, that is, those to be spawned during the reproductive period. Based on this, the absolute average fecundity for $S$. piaba was estimated as 441 oocytes $( \pm 178.08)$. Similar results were observed for other cheirodontines of similar size, as $S$. calliurus with 406 oocytes (Gelain et al. 1999) and C. ibicuhiensis with 635 (Braun et al. 2000) and 513 oocytes (Oliveira et al. 2002). When the relative fecundity is compared, $S$. piaba has a relatively higher value (0.74 oocytes $/ \mathrm{mg}$ ), than C. ibicuhiensis with 0.5 oocytes per $\mathrm{mg}$ (Oliveira et al. 2002) and S. calliurus with 0.6 oocytes per mg (Gelain et al. 1999).

Relationships between absolute fecundity and standard length, and absolute fecundity and total weight, indicate an increase in fecundity, proportionally to the fish increase in size and weight. Bagenal \& Braum (1978) and Wootton (1991) also observed an exponential relationship between the number of oocytes and female weight.

The fin ray hooks are bone extensions appearing in the fin rays of males of various species of the family Characidae. They are used as characters in species identification for this family, as well as in the definition of some supra specific taxa in Cheirodontinae (Malabarba, 1998) or other characid groups. In the genus Serrapinnus these hooks become progressively widened, laminar and triangular, forming a serrated margin in the posterior face of the rays. In males of S. piaba, rays with hooks in the anal fin expand in the cephalo-caudal direction, becoming progressively fused, transforming the first anal fin rays in rigid structures formed by a single piece, being considered an apomorphy compared to regularly segmented rays of the other characids (Malabarba, 1998). No information is available, however, about the process of development of these structures.

According to Wiley \& Collette (1970) the hooks can serve as contact organs during courtship. Garutti (1990) proposed that fin hooks in characids develop only during the reproductive stage, being subsequently lost, based on the observation of the absence of fin hooks in Astyanax bimaculatus (Linnaeus, 1758) after the reproductive period. Andrade et al. (1984), however, studying the same species, observed hooks in males during the 18 months of their experiment, suggesting that it is constant in adult males of this species. Silva (1996) also found hooks in males after the reproductive period. It was not possible to investigate hook development in S. piaba, due to the reduced number of fishes in maturation and the lack of immature individuals, but hook permanence in males all along the year and outside the female's reproductive period was evident.

\section{Acknowledgments}

We are grateful to Dr. Luiz R. Malabarba for comments on this manuscript and to Liliane de Lima Gurgel Souza, Kaline Dantas Magalhães, and Naissandra Bezerra da Silva of the Laboratório de Fisiologia e Ecologia de Peixes, UFRN, for their help during field work. Financial support was provided by CNPq (Proc.464545/00-5).

\section{Literature Cited}

Adebisi, A. A. 1987. The relationships between the fecundities, gonadosomatic indices and egg sizes of some fishes of Ogun River, Nigéria. Archiv fuer Hydrobiologie, 111 (1):151-156.

Andrade, D. R., E. Menin \& S. P. Ribeiro. 1984. Periodicidade da característica sexual secundária em Astyanax bimaculatus (Linnaeus, 1758) Pisces, Characidae. Revista Seiva, 44 (93): 9-12.

Azevedo, M. A., L. R. Malabarba \& C. B. Fialho. 2000. Reproductive biology of the inseminated Glandulocaudine Diapoma speculiferum Cope, 1894 (Actinopterygi: Characidae). Copeia, 2000 (4): 983-989.

Bagenal, T. \& E. Braum. 1978. Eggs and early life history. Pp.165201. In: Bagenal, T. (Ed). Methods for assessment of fish production in fresh-waters. Oxford, Blackwell Sc. Publ. $348 \mathrm{p}$.

Bye, V. J. 1989. The role of environmental factors in the timing of reproductive cycles, p. 187-215. In: Potts, G. W. \& R. J. Wootton (Eds). Fish reproduction: strategies and tatic. Academic Press, San Diego, CA. 410 p.

Braun, A. S., D. dos S. Lewis \& N. F. Fontoura. 2000. Biologia reprodutiva de Cheirodon ibicuhiensis (Eigenmann, 1915) na lagoa Fortaleza, Cidreira, Rio Grande do Sul, Brasil (Teleostei: Characidae: Cheirodontinae). Comunicações do Museu de Ciências e Tecnologia da PUCRS. Sér.Zool., 13 (2): 159-166.

Burns, J. R., S. Weitzman \& L. R. Malabarba. 1997. Insemination in eight species of Cheirodontinae fishes (Teleostei: Characidae: Cheirodontinae). Copeia, (2): 433-438.

Garutti, V. 1990. Caráter sexual secundário em Astyanax bimaculatus (Ostariophysi, Characidae) relacionado às nadadeiras anal e pélvicas. Naturalia, 15: 109-119.

Gelain, D., L. R. Malabarba \& C. B. Fialho. 1999. Biologia reprodutiva de Serrapinnus calliurus (Characidae, Cheirodontinae) do arroio do Ribeiro, Barra do Ribeiro, Rio Grande do Sul, Brasil. Comunicações do Museu de Ciências e Tecnologia da PUCRS, Sér. Zool., (12): 71-82.

Hartz, S. M., A. G. Martins \& A. C. Peret. 1994. Fecundidade de Cyphocharax voga (Hensel, 1869) na lagoa Emboaba, Rio Grande do Sul, Brasil. Comunicações do Museu de Ciências e Tecnologia da PUCRS, Sér. Zool., (76): 161-165.

Malabarba, L. R. 1998. Monophyly of Cheirodontinae, characters and major clades. P.193-233. In: Malabarba, L. R., R. E. Reis, R. P. Vari, Z. M. S. Lucena \& C. A. S. Lucena. Phylogeny and Classification of Neotropical Fishes. Porto Alegre, EDIPUCRS, 603p.

Nóbrega-Júnior, O. B. 1986. Diagnóstico ambiental do município de Extremoz. Monografia de Bacharelado em Geologia. Departamento de Geologia do Centro de Ciências Exatas. Universidade Federal do Rio Grande do Norte, Natal, Brasil. 172p.

Oliveira, C. L. C. 2003. Análise comparada de caracteres reprodutivos e da glândula branquial de duas espécies de Cheirodontinae (Teleostei: Characidae) M. Sc. Dissertation, Universidade Federal do Rio Grande do Sul, Porto Alegre, Brasil. 80p. 
Oliveira, C. L. C., C. B. Fialho \& L. R. Malabarba. 2002. Período reprodutivo desova e fecundidade de Cheirodon ibicuhiensis Eigenmann, 1915 (Ostariophysi: Characidae) do arroio Ribeiro, Rio Grande do Sul, Brasil. Comunicações do Museu de Ciências e Tecnologia da PUCRS, Sér. Zool., Porto Alegre, 15 (1): 3-14.

Santos, E. P. dos. 1978. Dinâmica de populações aplicada à pesca e piscicultura. São Paulo, EDUSP. 129 p.

Sendra, E. D. \& L. R. Freire. 1981. Estudio demográfico de Cheirodon interruptus (Pisces Tetragonopteridae) de la laguna Chascomus. I. Crecimiento. Limnobios, 2 (2): 111-126.

Silva, J. V., D. R. Andrade \& W. Y. Okano. 1996. Desenvolvimento sexual e crescimento de lambaris-tambiú, Astyanax bimaculatus Linnaeus, 1758 submetidos a diferentes tipos de alimentação. Arquivo Brasileiro de Medicina Veterinária e Zootecnia, 14 (supl. 1):33-38.

Vazzoler, A. E. \& N. A. Menezes. 1992. Síntese de conhecimentos sobre o comportamento reprodutivo dos Characiformes da América do Sul (Teleostei, Ostariophysi). Revista Brasileira de Biologia, 52 (4): 627-640.
Vazzoler, A. E. 1996. Biologia da reprodução de peixes teleósteos: teoria e prática. Maringá, EDUEM. 169p.

Wiley, M. L. \& B. B. Collette. 1970. Breeding tubercles and contact organs in fishes: their occurrences, structure and significance. Bulletin of the American Museum of Natural History, 143 (3):145-216.

Winemiller, K. O. 1989. Patterns of variation in life history among South American Fishes in Seasonal Enviroments. Oecologia, 81:225-241.

Wotton, R. G. 1991. Ecology of Teleost Fishes. London, Chapman \& Hall, 404p.
Received June 4, 2003 Accepted September 19, 2003 